\title{
Role of cGMP in fat and metabolism
}

\author{
Alexander Pfeifer*, Ana Kilić, Linda Hoffmann \\ From 6th International Conference on cGMP: Generators, Effectors and Therapeutic Implications \\ Erfurt, Germany. 28-30 June 2013
}

\section{Background}

The cGMP pathway regulates a large spectrum of physiological processes including metabolism. Our aim is to elucidate the cGMP signaling cascade in adipose tissue. Two types of fat tissue can be distinguished in mammals: white adipose tissue (WAT), which is the biggest storage of energy, and brown fat (BAT) that can dissipate energy as heat (non-shivering thermogenesis). We and others found that cGMP enhances differentiation of brown and white adipocytes [1-4].

\section{Methods and results}

In our studies, we initially focused on protein kinase $G$ (PKG/cGK), which is expressed both in white and brown adipocytes. Using gain- and loss-of-function models, we found that PKG is the major receptor for cGMP in brown adipocytes. We investigated the downstream targets of PKG and found a novel negative feedback loop that regulates cGMP levels. Importantly, in the presence of increased cGMP levels, we found an enhanced development of brown-like adipocytes, so-called beige or brite (brown in white) cells both in vitro and in vivo. These data indicate that cGMP not only enhances development of "classical" brown adipocytes, but also promotes development of beige cells.

Therefore, we studied the effect of cGMP in white adipocytes in more detail. Lentiviral overexpression of PKG enhanced differentiation of white adipocytes. Moreover, PKG induced the expression of a brown-like adipogenic program in white fat cells. Treatment of mice with the PDE inhibitor sildenafil for only 7 days promoted "browning" of WAT. Further studies regarding the cGMP signaling cascade upstream of PKG revealed that both particulate as well as soluble guanylyl cyclases are the source of cGMP in adipocytes.

\footnotetext{
* Correspondence: alexander.pfeifer@uni-bonn.de Institute of Pharmacology and Toxicology, Sigmund-Freud-Str. 25, D-53105
} Bonn, Germany

C 2013 Pfeifer et al; licensee BioMed Central Ltd. This is an Open Access article distributed under the terms of the Creative Commons Attribution License (http://creativecommons.org/licenses/by/2.0), which permits unrestricted use, distribution, and reproduction in any medium, provided the original work is properly cited.

\section{Conclusion}

In conclusion, cGMP is essential for normal differentiation of white and brown adipocytes. The cGMP/PKG pathway also induces "browning" of white fat and thus could be a promising target for developing novel therapies to treat metabolic diseases that are associated with imbalances in energy homeostasis including obesity and cachexia.

\section{Published: 29 August 2013}

\section{References}

1. Bordicchia M, Liu D, Amri EZ, Ailhaud G, Dessì-Fulgheri P, Zhang C, Takahashi N, Sarzani R, Collins S: Cardiac natriuretic peptides act via p38 MAPK to induce the brown fat thermogenic program in mouse and human adipocytes. J Clin Invest 2012, 122:1022-1036.

2. Haas B, Mayer P, Jennissen K, Scholz D, Berriel Diaz M, Bloch W, Herzig S, Fässler $\mathrm{R}$, Pfeifer A: Protein kinase $\mathrm{g}$ controls brown fat cell differentiation and mitochondrial biogenesis. Sci Signal 2009, 2:ra78.

3. Miyashita K, Itoh H, Tsujimoto H, Tamura N, Fukunaga $Y$, Sone M, Yamahara K, Taura D, Inuzuka M, Sonoyama T, Nakao K: Natriuretic peptides/cGMP/cGMP-dependent protein kinase cascades promote muscle mitochondrial biogenesis and prevent obesity. Diabetes 2009, 58:2880-2892

4. Nisoli E, Clementi E, Paolucci C, Cozzi V, Tonello C, Sciorati C, Bracale R, Valerio A, Francolini M, Moncada S, Carruba MO: Mitochondrial biogenesis in mammals: the role of endogenous nitric oxide. Science 2003, 299:896-899.

doi:10.1186/2050-6511-14-S1-025

Cite this article as: Pfeifer et al:: Role of cGMP in fat and metabolism. BMC Pharmacology and Toxicology 2013 14(Suppl 1):O25. and take full advantage of:

- Convenient online submission

- Thorough peer review

- No space constraints or color figure charges

- Immediate publication on acceptance

- Inclusion in PubMed, CAS, Scopus and Google Scholar

- Research which is freely available for redistribution

\section{Submit your next manuscript to BioMed Central}

\section{Biomed Central}

